\title{
Measurement of intracellular mediators in enterocytes isolated from jejunal biopsy specimens of control and cystic fibrosis patients
}

\author{
B W Hitchin, P R M Dobson, B L Brown, J Hardcastle, P T Hardcastle, C J Taylor
}

\begin{abstract}
A method that maximises the yield of viable enterocytes has been developed for the isolation of enterocytes from human jejunal biopsy specimens. These enterocytes have been used to study the values of intracellular free calcium and the rises in adenosine $3^{\prime} 5^{\prime}$-cyclic monophosphate (cAMP) induced by secretagogues in normal and cystic fibrosis cells. Basal intracellular free calcium of cystic fibrosis enterocytes, measured fluorimetrically with fura-2, was within the range of the basal intracellular free calcium of non-cystic fibrosis enterocytes (cystic fibrosis $263 \mathrm{nmol} / \mathrm{l}$; non-cystic fibrosis $287 \mathrm{nmol} / \mathrm{l})$. Changes in intracellular free calcium were observed after exposure to ionomycin: a $100 \mathrm{nmol} / \mathrm{l}$ solution induced a $2 \cdot 5$ fold increase in intracellular free calcium in the cystic fibrosis enterocytes and a $\mathbf{2 \cdot 2}$ fold increase in the intracellular free calcium concentration of the non-cystic fibrosis enterocytes. Basal cAMP values were not significantly different between cystic fibrosis and noncystic fibrosis enterocytes (cystic fibrosis $\mathbf{5 7 5}$ fmol/100 000 cells; non-cystic fibrosis $716 \mathrm{fmol} /$ 100000 cells, $p>0.05$ ) and the enterocyte cAMP value increased in response to stimulation with prostaglandin $\mathbf{E}_{2}(7 \mu \mathrm{mol} / \mathrm{l})$ (cystic fibrosis 2.2 fold increase over basal, $p<0.05$; non-cystic fibrosis 1.9 fold stimulation over basal, $p<0.05)$ and vasoactive intestinal polypeptide $(100 \mathrm{nmol} / \mathrm{l})$ (cystic fibrosis $7 \cdot 1$ fold increase over basal, $p<0.05$; non-cystic fibrosis 5.8 fold increase over basal, $p<0.05$ ). There was no significant difference in the magnitude of the response between cystic fibrosis and non-cystic fibrosis enterocytes $(p>0.05)$. These results indicate that the cystic fibrosis defect in the small intestine, as in other affected epithelia, seems to be distal to the production of second messengers. The small intestine is therefore an appropriate model in which to study the biochemical defect in cystic fibrosis.
\end{abstract}

Cystic fibrosis is an autosomal recessive disease, characterised by deficient chloride permeability in epithelia, including sweat glands, ${ }^{12}$ airways, ${ }^{3-5}$ and intestine. ${ }^{67}$ Although the gene coding for a protein associated with the defect has recently been identified, ${ }^{8-10}$ the exact biochemical nature of the defect remains unknown. It has been localised, however, to the apical membrane of the affected cells, where regulation of the chloride channels seems to be impaired,"12 leading to a failure of the chloride secretory mechanism. Chloride secretion is an electrogenic process which increases transepithelial electrical activity, ${ }^{13}$ and this can be detected as a rise in short circuit current. In our previous studies, changes in transepithelial electrical activity have been used to detect changes in ion transport across the small bowel of biopsy material from children with and without cystic fibrosis. ${ }^{7}$ These studies have shown that while intestinal tissue from non-cystic fibrosis patients responded to a variety of secretagogues with an activation of chloride secretion, cystic fibrosis tissue failed to exhibit such a response to all secretagogues tested, ${ }^{7}$ indicating the absence of a functional mechanism for chloride secretion. Both groups of tissue showed a normal response to mucosal glucose, indicative of tissue viability. Thus the intestine, like the epithelia of the airways ${ }^{3-5}$ and sweat glands, ${ }^{12}$ fails to transport chloride in response to stimulation by agents that act via the second messenger, adenosine 3' 5'-cyclic monophosphate (cAMP). In contrast to airway tissues, ${ }^{5} .11^{11}$ is the intestine also fails to transport chloride in response to secretagogues that act via changes in intracellular calcium, ${ }^{67}$ or guanosine 3' $5^{\prime}$-cyclic monophosphate (cGMP). ${ }^{15}$ The calcium ionophore A23187 did, however, induce a small short circuit current change in some cystic fibrosis biopsy specimens, ${ }^{7}$ while barium chloride, which stimulates intestinal secretion by releasing intracellular calcium, ${ }^{17} 18$ also increased the short circuit current in both control and cystic fibrosis biopsy specimens, ${ }^{19}$ suggesting that the mechanism for receptor operated increase of intracellular calcium may be impaired in the intestine of patients with cystic fibrosis. To determine whether abnormalities in epithelial ion transport in the small intestine of patients with cystic fibrosis reflect abnormal regulation of second messenger concentrations, cytosolic free calcium and cAMP values of enterocytes isolated from human jejunal biopsy specimens from cystic fibrosis and non-cystic fibrosis (control) patients were measured.

\section{Methods}

Fura 2/AM and ionomycin were purchased from Calbiochem, Cambridgeshire. $\left({ }^{3} \mathrm{H}\right)$-inulin and adenosine $3^{\prime} 5^{\prime}$-cyclic monophosphoric acid 2'$\mathrm{O}$-succinyltryosine ( $\left.{ }^{125} \mathrm{I}\right)$-methylester were from Amersham International, Amersham, Buckinghamshire. RPMI-1640, phosphate buffered saline (PBS), and penicillin and streptomycin were from Gibco-Europe, Paisley, Strathclyde. Fetal calf serum (FCS) was obtained from Northumbria Biologicals, Northumberland. Vasoactive intestinal polypeptide (VIP) was obtained from Peninsula Laboratories, 
Merseyside. Prostaglandin $\mathrm{E}_{2} \quad\left(\mathrm{PGE}_{2}\right), 3-$ isobutyl-1-methylxanthine (IBMX), bovine serum albumin (BSA) fraction $\mathrm{V}$, hyaluronidase type I-S, and soybean trypsin inhibitor type I-S were from Sigma Chemical Co, Poole, Dorset.

Fura $2 / A M$ and IBMX were dissolved in dimethylsulphoxide (DMSO) and were stored at $-20^{\circ} \mathrm{C}$. The Fura $2 / \mathrm{AM}$ was stored in the dark under argon at a stock concentration of $2 \mathrm{mmol} / \mathrm{l}$, while the IBMX was stored at a stock concentration of $0.5 \mathrm{mmol} / \mathrm{l}$. $\mathrm{PGE}_{2}$ was dissolved in ethanol and stored at $-20^{\circ} \mathrm{C}$ at a stock concentration of $10 \mathrm{mg} / \mathrm{ml}$. The concentration of DMSO in the incubations did not exceed $0.01 \%$, and the concentration of ethanol did not exceed $0.001 \%$.

\section{EXPRESSION OF RESULTS}

The statistics used were Student's $t$ tests, paired or unpaired as appropriate. The level of statistical significance was set at $\mathrm{p}<0 \cdot 05$. Data are expressed as mean (SD), with the number of experiments in parentheses. Each experiment was performed on a separate enterocyte preparation.

\section{ISOLATION OF ENTEROCYTES}

\section{Rat tissue}

Male 200-250 g Wistar rats fed ad libitum were used for the preparation of enterocytes. The rats were killed by cervical dislocation and the small intestine was quickly removed and flushed free of contents with ice cold PBS. The intestine was opened longitudinally to form a sheet, and the tissue sheets were divided up into approximately $1 \mathrm{~mm}^{3}$ slices. The tissue was washed three times in sterile tissue medium (RPMI-1640 medium containing $25 \mathrm{mmol} / \mathrm{l} \mathrm{HEPES}, 2 \mathrm{mmol} / \mathrm{l}$ glutamine, $0.01 \%$ trypsin inhibitor, $100 \mathrm{U} / \mathrm{ml}$ penicillin, and $100 \mu \mathrm{g} / \mathrm{ml}$ streptomycin) and transferred to oxygen saturated tissue medium containing $10 \%$ FCS and $0.15 \mathrm{mg} / \mathrm{ml}$ hyaluronidase. It was then incubated over a range of times at $4^{\circ} \mathrm{C}$ to allow the enzyme to penetrate the tissue without dissociation of the enterocytes. Excess medium was decanted off to leave moist tissue, and the enterocytes were released by gentle tituration of the tissue after a further 30 minutes incubation at $37^{\circ} \mathrm{C}$ under an atmosphere of $100 \%$ oxygen. The released enterocytes were collected by centrifugation at $100 \mathrm{~g}$ for two minutes, washed twice with tissue medium containing $0.1 \%$ BSA by resuspension and centrifugation, and then counted using either a haemocytometer or a Coulter counter. They were finally resuspended in experimental medium at the appropriate cell concentration for the experiment.

\section{Human tissue}

Tissue samples for cAMP determinations were obtained from five children with cystic fibrosis (mean age 3.7 years, range 1 month-12 years) and 13 control children (mean age 6 years, range 4 months-17 years). In one child a biopsy was performed to confirm the diagnosis of cystic fibrosis in the face of conflicting sweat test results; the remaining four children were under investigation for malabsorption that was unresponsive to pancreatic enzymes. Partial villus atrophy was found in one cystic fibrosis patient associated with a cryptosporadia infection. The control children underwent biopsy as part of their investigation for chronic diarrhoea or failure to thrive. Tissue samples used for calcium determinations were obtained from two cystic fibrosis patients ( 2 months and 2 years of age) and nine control children (mean age $7 \cdot 5$ years, range 11 months -29 years). Biopsy tissue was obtained either endoscopically from the distal duodenum or via a double port Crosby or Watson biopsy capsule from the proximal jejunum and placed on ice in oxygen saturated tissue medium containing $0 \cdot 1 \% \mathrm{BSA}$. The tissue was divided into $1 \mathrm{~mm}^{3}$ pieces and the enterocytes were isolated as described for rat tissue.

\section{ENTEROCYTE VIABILITY}

Viability was assessed by the ability of the enterocytes to exclude $0.05 \%$ trypan blue, and by assessing the cellular values of both potassium and adenosine triphosphate (ATP). For the trypan blue determinations, the enterocytes were mixed with trypan blue, left to stand at room temperature for two to five minutes, then the percentage of cells which excluded the dye was determined. ATP and potassium values were determined in cellular extracts prepared after rapid sedimentation of the cells from the medium by centrifugation for 15 seconds in a Beckman microfuge. The cells were extracted using $0.5 \%$ trichloroacetic acid. ATP in the cellular extracts was determined using a kit obtained from Sigma Diagnostics, while potassium values were determined by flame photometry using a Corning flame photometer. A correction was made for trapped extracellular fluid using $\left[{ }^{3} \mathrm{H}\right]$-inulin.

\section{CAMP ASSAY}

Enterocytes were resuspended in tissue medium containing $0 \cdot 1 \% \mathrm{BSA}$ at a cell concentration of 400000 cells $/ \mathrm{ml}$. Cells (100000) were preincubated with IBMX (1 mmol/l) for 10 minutes at $37^{\circ} \mathrm{C}$. $\mathrm{PGE}_{2}$ or VIP was added to a final concentration of $7 \mu \mathrm{mol} / 1$ or $100 \mathrm{nmol} / 1$ respectively, and the cells were incubated for a further period (as indicated from each experiment) at $37^{\circ} \mathrm{C}$. The reaction was terminated by the addition of ice cold ethanol to a final concentration of $65 \%$ (vol/ vol). The cAMP was extracted from the cells as described previously, ${ }^{20}$ and was measured by radioimmunoassay. ${ }^{21}$

\section{DETERMINATION OF INTRACELLULAR FREE $\mathrm{Ca}^{2+}$} VALUES

Enterocytes were resuspended in tissue medium containing $0 \cdot 1 \% \mathrm{BSA}$ at a cell concentration of 1-3 million cells $/ \mathrm{ml}$ and were incubated for 30 minutes at $37^{\circ} \mathrm{C}$ with $2 \mu \mathrm{mol} / \mathrm{l}$ Fura $2 / \mathrm{AM}$. The cells were diluted fivefold with tissue medium, washed'twice with fresh tissue medium and once with PBS, then resuspended in oxygen saturated study buffer $(137 \mathrm{mmol} / \mathrm{l} \mathrm{NaCl}, 5 \mathrm{mmol} / \mathrm{l} \mathrm{KCl}$, $0.4 \mathrm{mmol} / \mathrm{l} \mathrm{MgSO} 4,0.5 \mathrm{mmol} / \mathrm{l} \mathrm{MgCl}_{2}, 0.4$ 

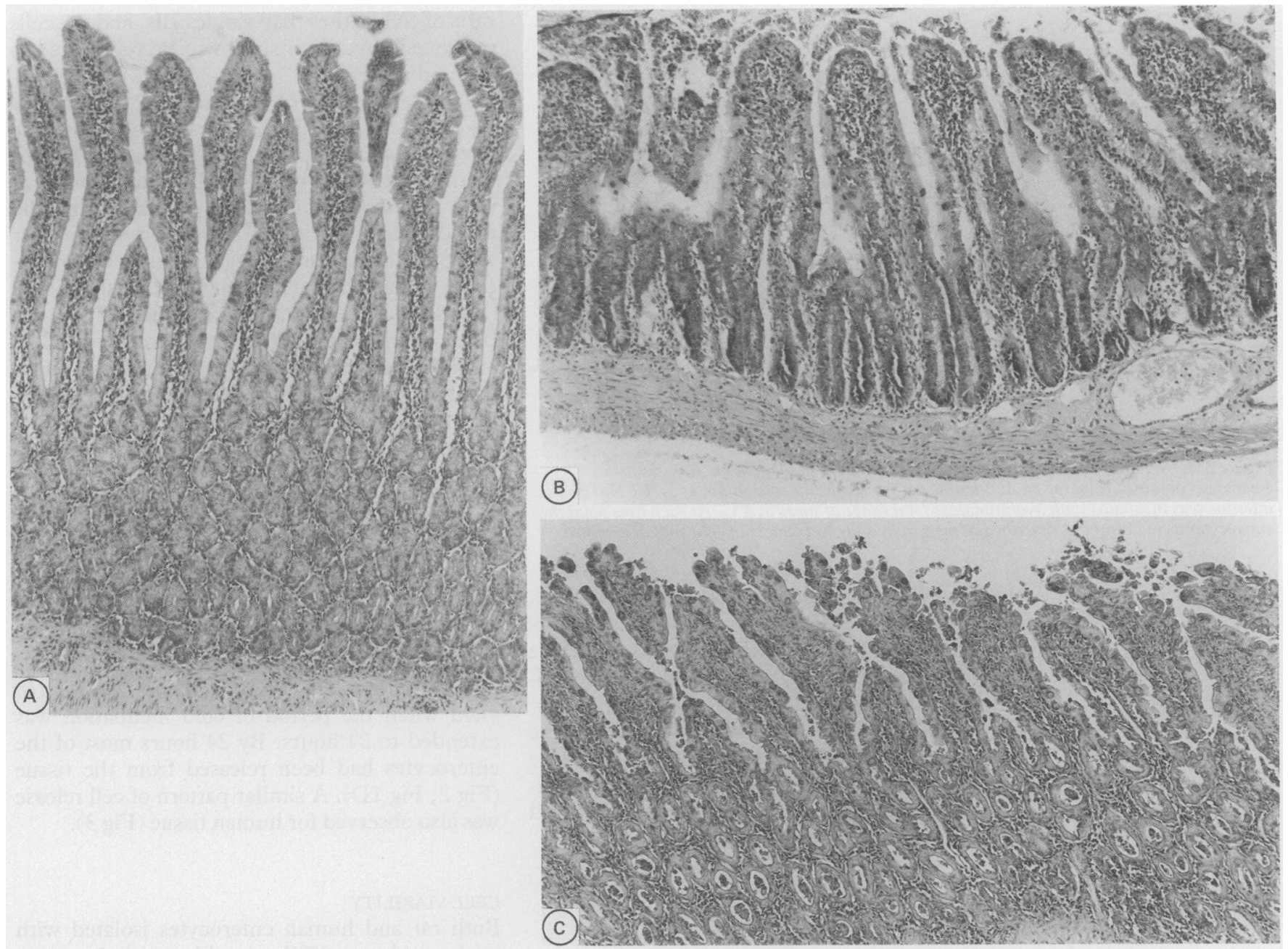

Figure 1: Histological sections of rat small intestine incubated with

hyaluronidase (original magnification $\times 90)$. $(A$

before hyaluronidase

treatment, (B) after 30 minutes incubation at $37^{\circ} \mathrm{C}$ (C) after 120 minutes incubation at $37^{\circ} \mathrm{C}$, and $(D$ after 24 hours pretreatment at $4^{\circ} \mathrm{C}$ followed by 30 minutes at $37^{\circ} \mathrm{C}$. The cells were isolated as described in the text, and the remaining tissue was processed for histological section.

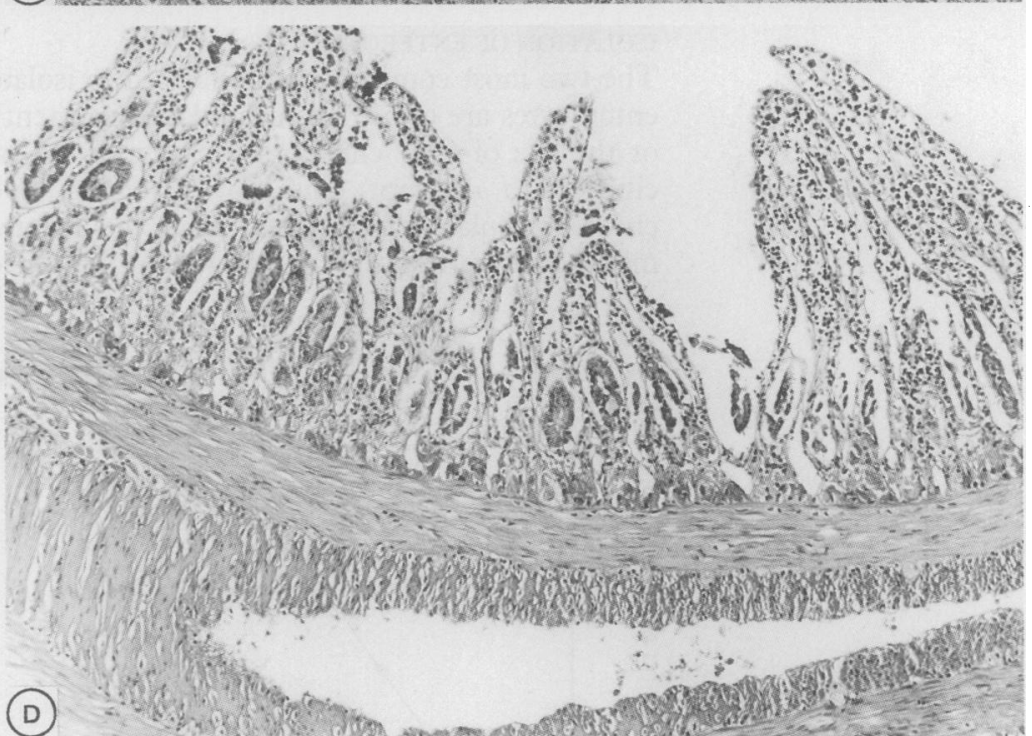

$\mathrm{mmol} / 1 \mathrm{NaH}_{2} \mathrm{PO}_{4}, 1 \mathrm{mmol} / 1 \mathrm{CaCl}_{2}, 10 \mathrm{mmol} / \mathrm{l}$ glucose, $1 \mathrm{mmol} / \mathrm{l}$ glutamine, $20 \mathrm{mmol} / 1 \mathrm{HEPES}$, $\mathrm{pH} \mathrm{7.4)}$ at a concentration of $0.5-1$ million cells/ $\mathrm{ml}$.

Fluorescence measurements were made on a Perkin-Elmer LS-5B luminescence spectrometer with excitation wavelength at $340 \mathrm{~nm}$ ( $5 \mathrm{~nm}$ slit) and emission wavelength at $510 \mathrm{~nm}$ $(10 \mathrm{~nm}$ slit). Enterocytes $(3 \mathrm{ml})$ were placed in a stirred cuvette at room temperature, and intracellular free calcium was measured essentially as described by Tsien $e t a l^{22}$ as modified by Wrench

$a l .^{23}$ The maximum fluorescence (Fmax) was determined after the addition of $10 \mu \mathrm{mol} / \mathrm{l}$ digitonin to lyse the cells and the minimum tion of $100 \mu \mathrm{mol} / \mathrm{l}$ manganese chloride. However, a true Fmax was not obtained using this method since the enterocytes tended to aggregate and sediment after addition of the digitonin, causing the calcium fluorescence to rise initially but then apparently to fall. A similar effect was observed when the enterocytes were lysed using Triton X-100. Ionomycin $(100 \mu \mathrm{mol} /$

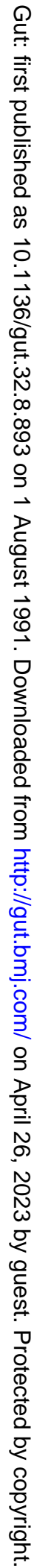
fluorescence (Fmin) was obtained by the addi- 


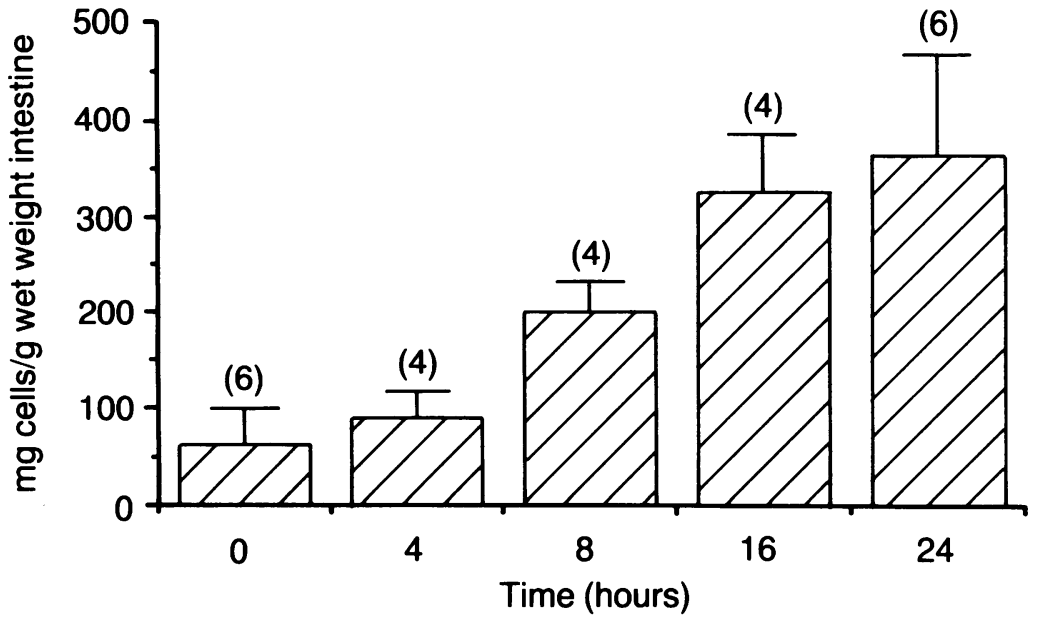

Figure 2: Effect of time of incubation with hyaluronidase in the cold on the yield of rat enterocytes obtained from rat small intestine after a 30 minute incubation at $37^{\circ} \mathrm{C}$. Rat small intestine was incubated with hyaluronidase for a range of times at $4^{\circ} \mathrm{C}$. At each time point the enterocytes were isolated as described in the text and the wet weight of cells was determined.

1), however, caused incomplete calcium release, but at higher concentrations the cells also aggregated. The reported calcium values are therefore likely to seem high. The intracellular free calcium was calculated using the equation, $\mathrm{Ca}^{2+}{ }_{\mathrm{i}}=$ $224 \times\{F-F \min \} /\{F \max -F\}$, where $F$ is the base line level of fluorescence and 224 is the dissociation constant of Fura 2 (in nmol/l). Minimum autofluorescence of the cells was noted and subtracted from all measurements.

\section{Results}

\section{ISOLATION OF ENTEROCYTES}

The two most common methods used to isolate enterocytes are either hyaluronidase treatment ${ }^{24}$ or the use of $\mathrm{Ca}^{2+}$ chelators such as EDTA or citrate $^{25}$ to distrupt epithelial structure. We chose to isolate enterocytes using the former method, since the latter method tends to produce

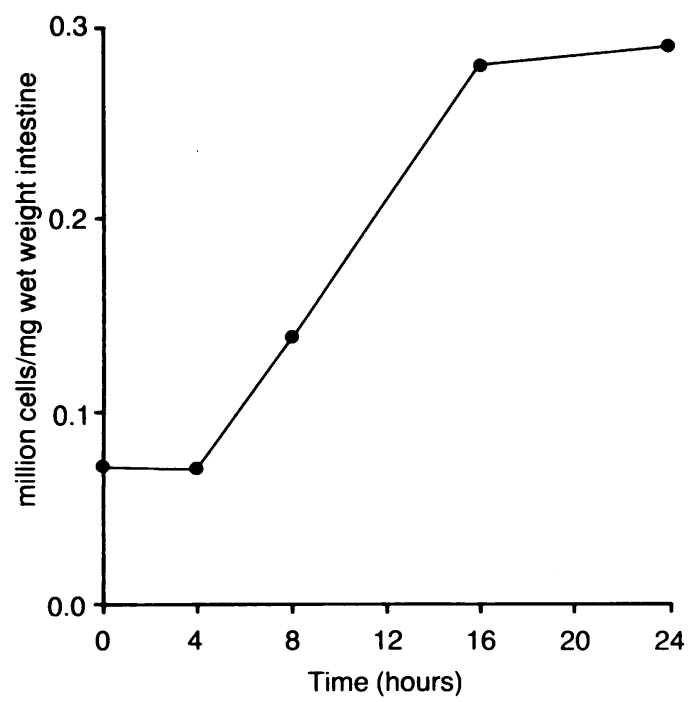

Figure 3: Effect of time of incubation with hyaluronidase in the cold on the yield of human enterocytes obtained from human jejunal biopsy specimens after a 30 minute incubation at $37^{\circ} \mathrm{C}$. Human small intestinal biopsy specimens were incubated with hyaluronidase for a range of times at $4^{\circ} \mathrm{C}$. At each time point the enterocytes were isolated as described in the text and the mean cell yield was determined. Each value represents a separate preparation. rafts of cells rather than single cells, and the cells produced have been shown to be permeable to $\mathrm{Ca}^{+}$and other ions. ${ }^{2627}$

Incubation of rat tissue with hyaluronidase for 30 minutes at $37^{\circ} \mathrm{C}$ without any cold exposure released enterocytes mainly from the villus tips (compare Fig 1A with Fig 1B). The amount of cells released was increased by incubating the tissue for longer with the enzyme, but even after a two hour incubation large amounts of enterocytes remained undissociated from the tissue (Fig 1C). Tissue samples were therefore incubated with hyaluronidase in the cold $\left(4^{\circ} \mathrm{C}\right)$ to allow the enzyme to penetrate the tissue in an inactive state without dissociation of the cells. RPMI-1640 has been used for organ culture of human intestine, ${ }^{28}$ so was used as the incubation medium in these experiments. After cold enzyme treatment, the tissue was warmed to $37^{\circ} \mathrm{C}$ for 30 minutes to activate the enzyme and release the cells. There was little increase in the cell yield obtained during a $37^{\circ} \mathrm{C}$ incubation after the initial four hours of cold exposure (Fig 2), but then there was a rapid increase in cell yield following warm incubation after four to 16 hours of cold incubation, with no further increase in yield when the period of cold incubation was extended to 24 hours. By 24 hours most of the enterocytes had been released from the tissue (Fig 2; Fig 1D). A similar pattern of cell release was also observed for human tissue (Fig 3).

\section{CELL VIABILITY}

Both rat and human enterocytes isolated with hyaluronidase at $37^{\circ} \mathrm{C}$ were able to exlude trypan blue after all time periods of cold enzyme exposure: the percentage of cells capable of excluding trypan blue increased with the time of prior cold exposure from $80-85 \%$ exclusion without prior cold exposure to $95-98 \%$ trypan blue exclusion after 24 hours prior cold exposure, presumably as the more senescent enterocytes from the villus tips were autolysed.

Basal potassium and ATP values of rat enterocytes remained approximately constant during the initial 20 hours of cold enzyme treatment and subsequent warm incubation at 233 to $270 \mathrm{nmol}$ potassium $/ \mathrm{mg}$ protein and $5 \cdot 2$ to $5.9 \mathrm{nmol} \mathrm{ATP} / \mathrm{mg}$ protein, but fell rapidly between 20 and 24 hours of cold exposure to 120 (8) [3] $\mathrm{nmol}$ potassium/mg protein and $3 \cdot 1(0 \cdot 4)$ [3] $\mathrm{nmol} \mathrm{ATP} / \mathrm{mg}$ protein by 24 hours. Values for potassium and ATP of human enterocytes were not obtained for early time points of cold enzyme treatment, since insufficient cells were released. However, the A.TP value observed in human enterocytes prepared after 20 hours of cold exposure was $5 \cdot 0(0 \cdot 3)[3] \mathrm{nmol} / \mathrm{mg}$ protein, which is comparable with the rat enterocyte value, and the potassium value was greater than that observed for rat enterocytes at 458 (56) [3] $\mathrm{nmol} / \mathrm{mg}$ protein.

Enterocytes were therefore routinely isolated from human jejunal biopsy specimens after incubation in the cold for 20 hours with hyaluronidase followed by a 30 minute incubation at $37^{\circ} \mathrm{C}$, since this procedure yielded the maximum number of single cells without compromising the cellular viability. 
Intracellular mediators in control and cystic fibrosis enterocytes

\begin{tabular}{lll}
\hline & Control & Cystic fibrosis \\
\hline Calcium $($ nmol/l) & & \\
Basal & $287(85)[9]$ & $263(37)[2]$ \\
Ionomycin $(100 \mathrm{nmol} / \mathrm{l})$ & $640(30)[3]$ & $663[1]$ \\
cAMP $($ fmol/100000 cells) & & \\
Basal & $716(304)[13]$ & $575(49)[5]$ \\
VIP $(100 \mathrm{nmol} / 1)$ & $4144(445)[3]$ & $4061(169)[3]$ \\
PGE $_{2}(7 \mu \mathrm{mol} / \mathrm{l})$ & $1190(445)[13]$ & $1251(426)[4]$ \\
\hline
\end{tabular}

cAMP = adenosine $3^{\prime} 5^{\prime}$-cyclic monophosphate; VIP = vascoactive intestinal polypeptide; $\mathrm{PGE}_{2}=$ prostaglandin $\mathrm{E}_{2}$

Basal and ionomycin stimulated changes in intracellular free calcium values of enterocytes isolated from jejunal biopsy

specimens of control and cystic fibrosis patients were determined as described in the text. For the cAMP determinations,

enterocytes were incubated for 10 minutes at $37^{\circ} \mathrm{C}$ with $1 \mathrm{mmol} / 1$

enterocytes were incubated for 10 minutes at $37^{\circ} \mathrm{C}$ with $1 \mathrm{mmo} /$
IBMX, and were then incubated for a further five minutes with either vehicle only (basal), VIP, or PGE 2 . The reaction was stopped and the cAMP extracted from the cells and analysed as described in the text.

\section{INTRACELLULAR FREE CALCIUM}

The basal values of intracellular free calcium did not seem to differ between normal and cystic fibrosis enterocytes (Table). The intracellular free calcium concentration of isolated enterocytes could be increased by exposing the cells to ionomycin, a non-fluorescent calcium ionophore, inducing a $2 \cdot 2$ fold increase in intracellular free calcium of normal enterocytes and a $2 \cdot 5$ fold increase in cystic fibrosis enterocytes (Table). However, the enterocytes isolated from both normal and cystic fibrosis biopsy specimens all failed to respond to secretagogues known to mobilise calcium (acetylcholine, carbachol, substance $P$, 5-hydroxytryptamine), which act mainly through cAMP (PGE 2 , VIP, dibutyrylcAMP), or which act through cGMP (Escherichia coli STa). A range of doses and exposure times to each of these agents failed to change the intracellular free calcium values within the enterocytes. The changes in intracellular free calcium values in normal and cystic fibrosis enterocytes in response to secretagogue challenge could not, therefore, be compared. This lack of effect of secretagogues on intracellular calcium values was also observed using rat enterocytes prepared by the method of Kimmich. ${ }^{24}$

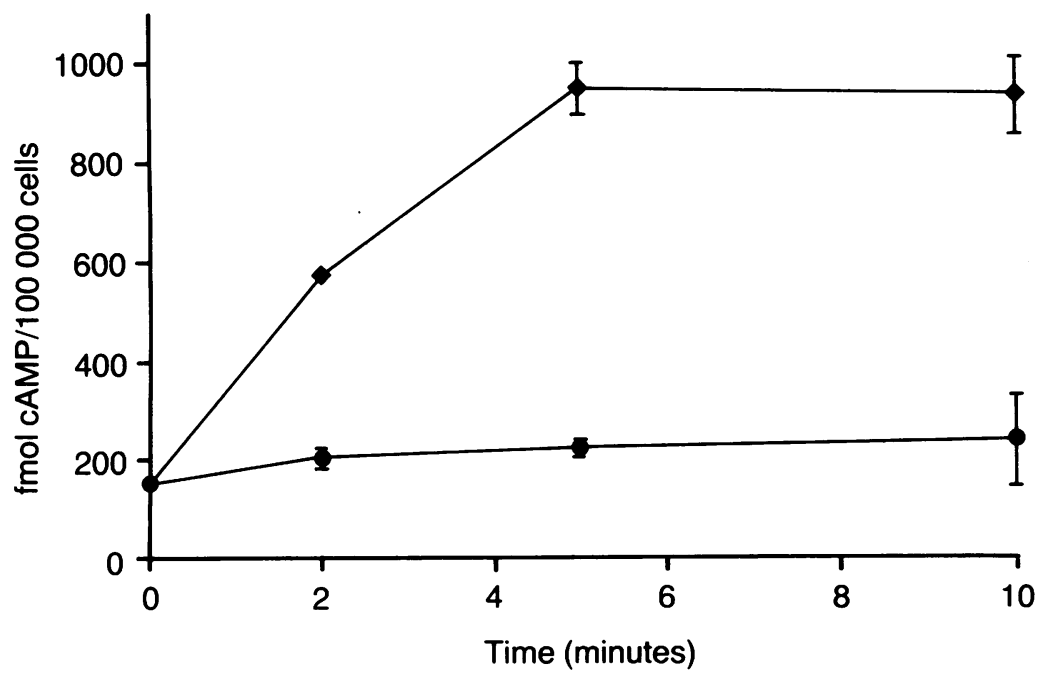

Figure 4: Time course of adenosine 3' $5^{\prime}$-cyclic monophosphate (cAMP) accumulation in human enterocytes in response to stimulation by $P G E_{2}$. Enterocytes (100000) were preincubated for 10 minutes at $37^{\circ} \mathrm{C}$ with $1 \mathrm{mmol} / \mathrm{l} 3$-isobutyl-1-methylxanthine (IBMX) then prostaglandin $E_{2}\left(P G E_{2}\right)(7 \mu \mathrm{mol} / \mathrm{l}$, closed diamonds) or vehicle (basal, closed circles) were added and the incubation was continued for a range of times up to 10 minutes. The reaction was added and the incubation was continued for a range of times up to 10 minutes. The reaction was from the cells and assayed as described in the text.

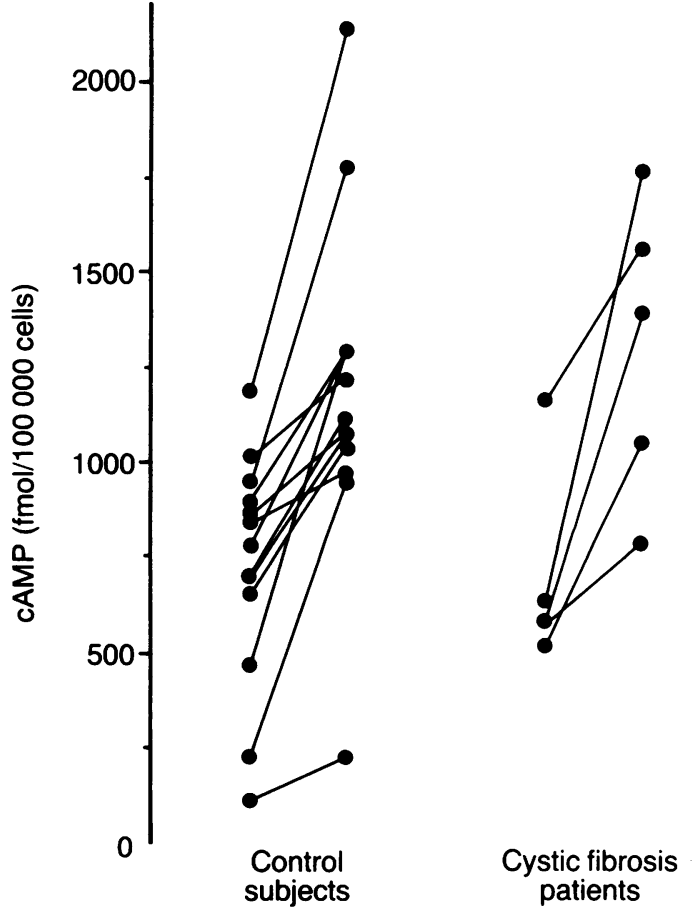

Figure 5: Effect of prostaglandin $E_{2}\left(P G E_{2}\right)$ stimulation on the accumulation of adenosine 3' $5^{\prime}$-cyclic monophosphate $(c A M P)$ in enterocytes isolated from intestinal biopsies of normal and cystic fibrosis patients. Enterocytes (100000) were preincubated for 10 minutes at $37^{\circ} \mathrm{C}$ with $1 \mathrm{mmol} / \mathrm{l} 3-i s o b u t y l-$ l-methylxanthine (IBMX). PGE $(\mu$ molll) or vehicle (ethanol) was added and the cells were incubated for a further 5 minutes at $37^{\circ} \mathrm{C}$. The cAMP was extracted from the cells and assayed as described in the text. The first value in each group represents the basal cAMP accumulated (vehicle only), and the second value represents the cAMP accumulated in response to $P G E_{2}$ stimulation. Each line represents a separate experiment, and each value is the mean of triplicate determinations.

\section{cAMP VALUES}

Enterocytes isolated from human jejunal biopsy specimens retained the ability to respond to stimulation by both $\mathrm{PGE}_{2}$ and VIP with an increase in cAMP. The basal value of cAMP production of cystic fibrosis enterocytes seemed to be lower than that of the normal enterocytes, although the difference was not significant, p $>0.05$ (Table). In the presence of the phosphodiesterase inhibitor, IBMX, the maximum rise in cAMP was observed after five minutes of $\mathrm{PGE}_{2}$ stimulation (Fig 4). $\mathrm{PGE}_{2}$ induced a 1.9 fold increase in cAMP production above basal values in normal enterocytes, $\mathrm{p}<0.05$ (Fig 5; Table), which was not significantly different $(p>0.05)$ from the 2.2 fold increase over basal values induced in cystic fibrosis enterocytes $(p<0.05)$. VIP was found to be a more potent stimulus for cAMP generation in both the normal and cystic fibrosis enterocytes. The cAMP values were increased 6.3 fold in the control enterocytes compared with a $7 \cdot 1$ fold rise in the cystic fibrosis enterocytes (Table), suggesting that the cystic fibrosis enterocytes respond as well as the normal enterocytes to VIP.

\section{Discussion}

A method has been developed for the isolation of enterocytes from human jejunal biopsy specimens which maximises the yield of viable enterocytes obtained. These enterocytes have been used to study the values of intracellular free 
calcium and the increase in cAMP induced by secretagogues in normal and cystic fibrosis cells. The results indicate that the cystic fibrosis enterocytes retain the ability to respond to secretagogue stimulation with an increase in the cAMP value, and there is not significant difference in either the basal cAMP value or in the response to stimulation between normal and cystic fibrosis enterocytes. Previously, similar results have been obtained using other epithelial tissues that are affected by cystic fibrosis (sweat ducts $^{41}$; airways tissues ${ }^{1442}$; salivary glands $^{43} ;$ rectum $^{44}$ ).

Basal intracellular calcium values of cystic fibrosis and normal enterocytes also seem to be similar, but although changes in intracellular calcium concentration could be induced by the ionophore ionomycin, they were consistently unresponsive to secretagogues that act via membrane receptors. This is probably not a consequence of membrane receptor impairment, since enterocytes isolated under identical conditions were capable of responding to PG and VIP stimulation with an increased cAMP accumulation. Thus some other factor, perhaps related to either the isolation procedure itself or to the viability of the enterocytes upon incubation, may contribute to the lack of detectable calcium responses. Basal calcium values for normal and cystic fibrosis nasal epithelium were reported by Murphy $e t a l^{29}$ and more recently by Boucher $e t$ $a l^{5}$ and both groups found no significant difference in the basal calcium concentrations between cystic fibrosis and normal cells. Although Boucher $e t a l^{5}$ found an increase in intracellular free calcium in response to stimulation by bradykinin which was equal in magnitude between normal and cystic fibrosis cells, Murphy et $a^{29}$ were unable to observe changes in intracellular calcium concentrations in response to agents that increase cAMP. While Murphy et al suggested that the lack of response may be a consequence of the disaggregation procedure, they concluded that it was more likely that substantial changes in intracellular calcium concentrations in response to cAMP accumulation are not a major feature of human respiratory epithelia. Values of intracellular calcium in mammalian enterocytes obtained using fluorescent indicators have not been previously reported, although values of intracellular calcium have been reported for chicken enterocytes, ${ }^{30}{ }^{31}$ and these cells have been shown to respond to secretagogue challenge with an increase in intracellular calcium. These responses were small (25-65 nmol/l changes), however, and were strongly influenced by age, species, and even diet of the donor chicken (Chang, personal communication). Furthermore, Chang and co-workers have been unable to obtain similar data for mammalian cells. At least one other group has also attempted to obtain values of intracellular calcium for mammalian enterocytes using fluorescent indicators, ${ }^{32}$ but without success. The mammalian enterocyte system does not, therefore, seem to be ideal for these types of studies. It may be that the changes in intracellular calcium values induced in enterocytes by secretagogue challenge are very small or localised to specific cellular pools in vivo, or both, so may be undetected in the in vitro system. Alternatively, calcium mobilisation may be of lesser importance in these tissues.

The results obtained with VIP in this study are particularly interesting in the light of recent reports of sparse innervation of cystic fibrosis nasal and small intestinal mucosae by fibres that contain immunoreactive VIP. ${ }^{33-35}$ There is not a generalised loss of these fibres since VIP immunoreactive fibres innervating the muscle layers and myenteric plexus of the intestine are largely unaffected. As there is evidence to suggest that VIP is the major non-cholinergic transmitter of secretomotor neurones, controlling water and electrolyte secretion in the small intestine and promoting an increase in blood flow to the mucosa, ${ }^{36-39}$ the deficiency of VIP containing neurones within the mucosa in cystic fibrosis was postulated to contribute to the pathogenesis of the disease. Our studies, however, show that the enterocytes of the intestinal mucosa of cystic fibrosis patients retain the ability to respond to VIP with an increase in cAMP production that was equal in size to the response obtained in normal tissue. Thus, despite the sparse innervation, the receptors for VIP seem to be present on the cystic fibrosis enterocytes and they also seem to be functionally coupled to adenylyl cyclase. This was also confirmed in another recent study of fetal intestine, ${ }^{40}$ in which the receptors for VIP were found to be present in equal abundance and to have similar biochemical and functional properties to those from normal intestine. Thus, the lack of innervation of VIP containing fibres to the intestinal mucosa does not seem secondary to a lack of functional VIP receptors, but may be brought about as a consequence of the ability of the enterocyte to attract or to sustain the fibres, perhaps as a result of an absent or abnormal membrane protein in the epithelial cells.

The gene coding for the cystic fibrosis defect has recently been identified and sequenced, and a putative structure determined for the defective protein. ${ }^{8-10}$ Called the cystic fibrosis transmembrane conductance regulator (CFTR), the protein is proposed to consist of five domains: two hydrophobic regions which comprise potential membrane spanning helices; two nucleotide binding folds; and a large cytoplasmic domain which contains consensus sequences for phosphorylation by protein kinase $\mathrm{C}$ and $\mathrm{cAMP}$ dependent kinase. Approximately $70 \%$ of cystic fibrosis patients seem to share a common mutation, a deletion of three nucleotides coding for a single phenylalanine residue at the centre of the first nucleotide binding domain. ${ }^{10}$ The CFTR shows considerable organisational and structural homology with a super-family of prokaryotic and eukaryotic transport proteins, all of which seem to couple ATP hydrolysis to the pumping of molecules into or out of the cell. ${ }^{45} \mathrm{By}$ analogy with these proteins, it has been proposed that the cystic fibrosis gene product may be an ATP dependent transport protein, although the nature of the transported molecule and the precise function of the CFTR, and its relation with chloride channel function, remains unclear. This is compounded by the fact that many of the details of the events leading to chloride secretion in normal epithelia are still unknown. It is 
uncertain whether the activated kinases directly affect the chloride channels themselves or a regulatory protein responsible for chloride channel activity (CFTR?), or whether the activation of a further kinase or phosphatase is involved. Thus, despite cloning of the cystic fibrosis gene and elucidation of the putative structure of the CFTR, we are still unclear about the site of action of the cystic fibrosis defect. It is evident, however, that the site of the defect is distal to the production of cAMP in all of the cell types, and will presumably occur at a site which is at or close to the chloride channel, at a point in the signal transduction cascade which is perhaps common to all of the signal transduction pathways. The development of a method for isolation of high yields of viable enterocytes from a single jejunal biopsy specimen described in this paper should facilitate the investigation of this defect in intestinal cells.

This work was supported by a grant from the Cystic Fibrosis Trust, UK.

1 Quinton PM. Missing Cl conductance in cystic fibrosis. Am $\mathcal{F}$ Physiol 1986; 251: C649-52.

2 Quinton PM. Defective epithelial ion transport in cystic fibrosis. Clin Chem 1989; 35: 726-30.

3 Knowles MR, Stutts MJ, Spock A, Fischer N, Gatzy JT, Boucher RC. Abnormal ion permeation through cystic fibrosis respiratory epithelium. Science 1983; 221: 1067-70.

4 Widdicombe JH, Welsh MJ, Finkbeiner WE. Cystic fibrosis decreases the apical membrane chloride permeability of monolayers cultured from cells of tracheal epithelium. Proc Natl Acad Sci USA 1985; 82: 6167-71.

5 Boucher RC, Cheng EHC, Paradiso AM, Stutts MJ, Knowles MR, Earp HS. Chloride secretory response of cystic fibrosis human airway epithelia. Preservation of calcium but no protein kinase $\mathrm{C}$ - and A-dependent mechanisms. $\mathcal{f}$ Clin Invest 1989; 84: 1424-31.

6 Berschneider HM, Knowles MR, Azizkhan RG, Boucher RC, Tobey NA, Orlando RC, et al. Altered intestinal chloride transport in cystic fiboris. FASEB F 1988; 2: 2625-9.

7 Taylor CJ, Baxter PS, Hardcastle J, Hardcastle PT. Failure to induce secretion in jejunal biopsies from children with cystic fibrosis. Gut 1988; 29: 957-62

8 Rommens JM, Iannuzzi MC, Kerem B-S, Drumm ML, Melmer G, Dean M, et al. Identification of the cystic fibrosis gene: chromosome walking and jumping. Science 1989; 245 1059-65.

9 Riordan JR, Rommens JM, Kerem B-S, Alon N, Rozmahel R, Grzelczak Z, et al. Identification of the cystic fibrosis gene:
cloning and characterization of complementary DNA. Science 1989; 245: 1066-73.

10 Kerem B-S, Rommens JM, Buchanan JA, Markiewicz D, Cox TK, Chakravarti A, et al. Identification of the cystic fibrosis gene: genetic analysis. Science 1989; 245: 1073-80.

11 Frizzell RA, Rechkemmer G, Shoemaker RL. Altered regulation of airway epithelial cell chloride channels in cystic fibrosis. Science 1986; 233: 558-60.

12 Boucher RC, Cotton CU, Gatzy JT, Knowles MR, Yankaskas $\mathrm{JR}$. Evidence for reduced $\mathrm{Cl}^{-}$and increased $\mathrm{Na}^{+}$permeability in cystic fibrosis human primary cultures. $\mathcal{F}$ Physio 1988; 405: 77-103.

13 Frizzell RA, Field M, Schultz SG. Sodium-coupled chloride transport by epithelial tissues. Am $\mathcal{F}$ Physiol 1979; 236 : F1-8.

14 Welsh MJ, Leidtke CM. Chloride and potassium channels in cystic fibrosis airway epithelium. Nature 1986; 322: 467-70.

15 Boucher RC, Cheng E, Stutts MJ, Knowles MR, Earp HS Selective induction of $\mathrm{Cl}^{-}$secretion in cystic fibrosis nasal epithelium by a calcium ionophore (A23187). Am Rev Respir Dis $1987 ; 135: 140 \mathrm{~A}$.

16 Baxter PS, Goldhill J, Hardcastle J, Hardcastle PT, Taylor CJ. Accounting for cystic fibrosis. Nature 1988; 335: 211 .

17 Hardcastle J, Hardcastle PT, Noble JM. The effects of barium chloride on intestinal secretion in the rat. $\mathcal{F}$ Physiol 1983; 344: 69-80.
18 Hardcastle J, Hardcastle PT, Noble JM. The secretory action of barium chloride in rat colon. 7 Physiol 1985; 361: 19-33.

19 Hardcastle J, Hardcastle PT, Goldhill J, Taylor CJ, Baxter PS Possible target for cystic fibrosis in the small intestinal epithelium [Letter]. Gut 1989; 30: 143-4.

20 Brown BL, Wojcikiewicz RJH, Dobson PRM, Robinson A, Irons LI. Pertussis toxin blocks the inhibitory effect of muscarinic cholinergic agonists on cyclic AMP accumulation and prolactin secretion in $\mathrm{GH}_{3}$ anterior pituitary tion and prolactin secretion in $\mathrm{GH}_{3}$ ante
tumour cells. Biochem $\mathcal{F}$ 1984; 223: $145-9$.

21 Harper JF, Brooker G. Femtomole sensitive radioimmunoassay for cyclic AMP and cyclic GMP after $2^{\prime} \mathrm{O}$ acetylation by acetic anhydride in aqueous solution. $\mathcal{F}$ Cyclic Nucleotide Res $1975 ; 1$ : 207-18.

22 Tsien RY, Pozzan T, Rink TJ. Calcium homoestasis in intact lymphocytes: cytosolic free calcium monitored with a new intracellular trapped fluorescent indicator. $\mathcal{F}$ Cell Biol 1982; 94: 325-34.

23 Wrench IJ, Brown TJ, Brown BL, Dobson PRM. The effect of fetal calf serum on intracellular calcium in $\mathbf{G H}_{3}$ cells. of fetal calf serum on intracellular calcium in

$24 \mathrm{Kimmich}$ GA. Preparation and characterization of isolated intestinal epithelial cells and their use in studying intestinal transport. In: Korn ED, ed. Methods in membrane biology. Vol 5. Transport. Oxford: Plenum Press, 1975.

25 Weiser MM. Intestinal epithelial cell surface membrane glycoprotein synthesis. I. An indicator of cellular differentiation. $\mathcal{F}$ Cell Biol 1973; 248: 2536-41.

26 Mian N, Pover WRF. The loss of cellular material from suspensions of isolated epithelial cells of guinea pig small intestine. Biomedicine 1974; 20: 186-91.

27 Velasco G, Dominguez P, Shears SB, Lazo PS. Permeability properties of isolated enterocytes from rat small intestine. properties of isolated enterocytes from
Biochim Biophys Acta 1986; 889: 361-5.

28 Trier JS. Organ culture of the mucosa of human small intestine. Meth Cell Biol 1980; 21: 365-84.

29 Murphy E, Cheng E, Yankaskas J, Stutts MJ, Boucher RC. Cell calcium levels of normal and cystic fibrosis epithelium. Pediatr Res 1988; 24: 79-84.

30 Chang EB, Brown DR, Wang NS, Field M. Secretagogueinduced changes in membrane permeability in chicken and chinchilla ileal mucosa. F Clin Invest 1986; 78: 281-7.

31 Hirose R, Chang EB. Effects of serotonin on $\mathrm{Na}^{+}-\mathrm{H}^{+}$exchange and intracellular calcium in isolated enterocytes. $A m \mathcal{F}$ Physiol 1988; 254: G891-7.

32 Velasco G, Shears SB, Michell RH, Lazo PS. Calcium uptake by intracellular compartments in permeabilized enterocytes. Effect of inositiol 1,4,5-trisphosphate. Biochem Biophys Res Commun 1986; 139: 612-8.

33 Heinz-Erian P, Dey RD, Flux M, Said SI. Deficient vasoactive intestinal peptide innervation in the sweat glands of cystic fibrosis patients. Science 1985; 229: 1407-8.

34 Heinz-Erian P, Said SI. Vasoactive intestinal peptide as regulator of exocrine function in cystic fibrosis. In: Said SI Mutt V, eds. Vasoactive intestinal peptide and related peptides. Ann NY Acad Sci 1988; 527: 568-73.

35 Wattachow DA, Furness JB, Gibbins IL, Little KE, Carter RF. Vasoactive intestinal peptide immunoreactive nerve fibres are deficient in intestinal and nasal mucosa affected by fyres are deficient in intestinal and nasal mucosa affected

36 Gaginella TS, Hubel KA, O'Dorisio JM. Effects of vasoactive intestinal peptide on intestinal chloride secretion. In: Said SI, ed. Vasoactive intestinal peptide. New York: Raven Press, 1982: 211-22.

37 Said S. Vasoactive intestinal peptide. $\mathcal{F}$ Endocrinol Invest 1986; 9: 191-200.

38 Donowitz M, Welsh MJ. Regulation of mammalian smal intestinal electrolyte secretion. In: Johnson LR, ed. Physiology of the gastrointestinal tract. New York: Rave Press, 1987: 1351-88.

39 Furness JB, Costa M. The enteric nervous system. Edinburgh: Churchill-Livingstone, 1987.

40 Chastre E, Bawab W, Faure C, Emami S, Muller F, Boue A et al. Vasoactive intestinal peptide and its receptors in fetuses with cystic fibrosis. Am $\mathcal{F}$ P hysiol 1989; 257: G561-9.

41 Sato K, Sato F. Defective beta-adrenergic response of cystic fibrosis sweat glands in vivo and in vitro. $\mathcal{F}$ Clin Invest 1984 73: 1763-71.

42 Widdicombe JH. Cystic fibrosis and $\beta$-adrenergic response of airway epithelial cell cultures. Am $\mathcal{F}$ Physiol 1986; 251 R818-22.

43 McPherson MA, Dormer RL, Bradbury NA, Dodge JA, Goodchild MC. Defective $\beta$-adrenergic secretory responses in submandibular acinar cells from cystic fibrosis patients. Lancet 1986; ii: 1007-8.

44 Goldstein JL, Nash NT, Al-Bazzaz F, Layden TL, Rao MC Rectum has abnormal ion transport but normal cAMP binding proteins in cystic fibrosis. Am $\mathcal{f}$ Physiol 1988; 254 : C719-24.

45 Higgins C. Protein joins transport family. Nature 1989; 341: 103. 